\title{
The Dilemma and Solution of Private Real Estate Enterprises Investment in Laos
}

\author{
Junhua Tang \\ International Business School \\ Yunnan University of Finance and Economics \\ Kunming China \\ 383464402@qq.com \\ Wei Zhang \\ International Business School \\ Yunnan University of Finance and Economics
}

\author{
Kunming China \\ 2437980429@qq.com \\ Qiqi Ding * \\ International Business School \\ Yunnan University of Finance and Economics \\ Kunming China \\ 1432823214@qq.com
}

\begin{abstract}
The reasons of the investment dilemma of private real estate companies in Laos are found in the paper by checking numerous data, cases and documents. The dilemma is about cross-cultural communication, management talent, funding supply material supply and progress. Then, countermeasures and suggestions are put forward to help companies solve the dilemma from the two aspects of the state and the company. It could help enterprises reduce the risk of international projects and do international business successfully.
\end{abstract}

Keywords-private real estate enterprise; investment dilemma; Laos

\section{INTRODUCTION}

The government has issued four rounds of policies to destock. So, it has relaxed restrictions on real estate purchases, strengthened credit support and tax relief after the Chinese economy entered the new normal. The cost of land in Southeast Asia is relatively low, and some countries are implementing urbanization to drive demand for real estate. Chinese private real estate companies have achieved short-term development overseas. However, the foreign investment of the industry has been hindered and development has become stagnant due to the limitations of the company, Chinese investment policies and the investment environment of host country, so there are a series of issues that need to be studied in depth.

The investment of real estate private enterprises in Laos is a complicated task and the plan of the project needs to be managed. The plan management has the characteristics of scientific, strict assessment, reasonable level, full approval, and timely and accurate features, which can ensure the efficiency of project implementation [13]. The enterprises should pay full attention to the preliminary tenders, sign contracts and establishing a risk control system in a timely manner when contracting international project [12]. Enterprises should combine their own resources and advantages, start multinational operations, and achieve complementarities when using resources on a global scale and it becomes the main form of international business operations [2]. Among them, the success of multinational corporate culture construction has become one of the key factors that affect the success of multinational operations and foreign investment [7]. In analyzing the performance and causes of cultural conflicts among multinational corporations, we should explore cultural conflicts and integration issues in multinational operations and cross-cultural management strategies to promote the healthy operation of multinational companies [5]. In terms of investment, Laotian government has adopted multiple measures to improve the investment environment and Laotian domestic investment in recent years [4]. Due to the restrictions of development $\mathrm{f}$ economic and social development, the Laotian government still has problems with the management and development value orientation in the promotion of trade cooperation with China [14].

Foreign investment is an important driving force for economic growth, so many countries continue to implement liberalization and promote policies to attract foreign investment [6]. In general, investment policies in various countries continue to develop in the direction of investment liberalization and facilitation. However, concerns over strategic industries or national security factors have led to the introduction of many new investment restrictions and control measures in various countries. [17]. The Laotian financial environment is loose, and foreign exchange control is gradually relaxing [8].

First of all, this paper analyzes the difficulties and causes of the private real estate enterprises investment and development projects in Laos through the review of large amounts of data and related policies. Then, proposing policy recommendations with reference. Finally, we draw a conclusion give a summary of the paper. Through in-depth analysis of dilemmas and solutions, it has practical application significance for managing and controlling the risk of international projects.

*Corresponding author 


\section{The Status Quo AND REASONS OF INVESTMENT}

\section{A. Reasons for Private Real Estate Enterprises Investment in}

\section{Laos}

In recent years, the economic development prospects of Laos have been widely favored due to the development of the power industry and the advancement of ASEAN integration. According to the statistical report submitted by the Ministry of Planning and Investment of Laos, Laotian GDP was 129.279 trillion kip and its per capita GDP was US\$2,408, of which, industrial growth was $12 \%$, accounting for $28.7 \%$ of GDP, and power industry growth was $39 \%$, accounting for $36.9 \%$ of GDP in 2016. The total investment reached 4.287 billion kip, which was a year-on-year increase of $24.2 \%$ in 2016. According to the Laotian Economic and Social News, Laotian economic development rate reached $6.8 \%$ in 2017. A good economic environment has provided Chinese private real estate enterprises with a driving force for investment. On the one hand, Chinese policies encourage private real estate enterprises to 'going out', adjust relevant policies, simplify the procedures for foreign investment, and issue relevant policies to provide policy convenience and investment orientation for overseas investment projects of enterprises. Moreover, the real estate industry in China is shrinking due to the slowdown in economic growth and the impact of policy controls. Therefore, in order to ease the pressure on domestic steel, cement and other building materials production and excess real estate inventory, many private real estate enterprises have begun to seek new markets overseas.

On the other hand, China is the largest source of foreign investment in Laos. Laotian high level of development in recent years has been closely linked with China. The two sides have also established a strategic partnership in politics and reduced political risks. In addition, Laos provides Chinese enterprises with facilities such as industrial protection and tax incentives. For example, equipment and special vehicles which are required for commercial real estate construction projects can be exempted from Import tariff, business taxes, and excise taxes, further promoting Chinese private real estate enterprises to invest in Laos.

\section{B. The Status of Investment in Laos of Private Real Estate}

\section{Enterprise}

Chinese real estate enterprises have rapidly expanded outward along the national capital and port cities along the Maritime Silk Road and along the Silk Road along the land. The transformation of private real estate enterprises is relatively easy and the degree of integration is stronger. The enterprises could further expand the scope of development to mining and processing of mineral resources, development and operation of tourism resources, research and development of agricultural science and technology, and the operations and services of urban business after familiarizing themselves with the local situation. Therefore, private real estate companies can expand faster. Chinese enterprises direct investment in Laos is mainly concentrated in the secondary industry. From 1991 to 2015, the accumulated amount was 4065.06 million US dollars, accounting for $77 \%$ of the total investment. There are a total of
362 projects. The growth period from 2007 to 2014 is faster than others, which the total investment increased from 134.04 million U.S. dollars in 2007 to 889.042 million U.S. dollars in 2014. Chinese investment in the secondary industry in Laos has directly or indirectly led the private real estate enterprises investment in Laos. Some of the local private real estate enterprises investment projects in Laos have even become local landmarks. For example, Sanjiang International Trade City, located in the Vientiane Traffic Fortress Lombassa, covers a total area of 160,000 square meters, and the building area is close to 70,000 square meters. It has become the largest comprehensive Chinese commodity market in Southeast Asia after nearly a decade of development.

Since 2013, countries along the "Belt and Road" have received a total of US $\$ 121$ billion in real estate investment from China, but they have included a large number of irrational investments by small and medium sized private enterprises and a large capital outflow. On June 26, 2017, "Several Opinions on Improving the Security Work of Overseas Enterprises and Foreign Investment" called for perfecting the statistical monitoring of overseas enterprises and foreign investment, and strengthening supervision and management. "Guiding Opinions on Further Guiding and Regulating the Direction of Overseas Investment (2017)" classifies investments in real estate, hotels and etc, which usually involve large amounts of capital, in the categories of restricted overseas investment. It is said that the private real estate enterprises investment in Laos has been subject to certain restrictions in the past two years.

\section{The Analysis of the Dilemma of Private Real}

\section{ESTATE ENTERPRISES INVESTMENT IN LAOS}

\section{A. Difficulties of Cross-Cultural Communication}

On the one hand, China and Laos are geographically adjacent to each other, but there is a huge difference in the cultures of the two countries, such as languages, customs and spending habits, and some Lao residents have negative views on Chinese enterprises and products. On the other hand, the decision entering the Laotian market is too hasty without understanding and being thoroughly familiar with the local environment [1]. They also lack the corresponding cultural and language talents who is contacting with the local government, enterprises, employees and the public. Difficulties in communication and communication make it easy to generate unnecessary misunderstandings and frictions, which bring greater obstacles and difficulties to the project, increase the risk of stagnation or even failure of the project, and in turn bring a considerable loss to the enterprise

\section{B. Lack of Top Management Talent}

Internationalized operation is a very complicated job and requires highly qualified personnel in terms of technology, management, law, finance, and marketing. On the one hand, enterprises are in short supply of comprehensive managerial talents with rich operational management experience and capable of operating international operations. Private real estate enterprises are often unable to grasp the latest international market dynamics, thereby greatly increasing the risk of 
operations [15]. On the other hand, the labor force quality in the Laotian market is generally low and there is a shortage of highly qualified personnel. Although local employee is cheap, they are more arbitrarily employed in foreign-funded enterprises and may temporarily resign at any time. It often leads to a serious drain on the training of Chinese enterprises own employees. The Lao government also explicitly stipulates the restrictions on the preferential employment of Lao citizens by foreign companies. It also stipulates that the number of foreign employees shall not exceed $10 \%$, the proportion of foreign employees in management positions shall not exceed $20 \%$. The problem of differences of culture among the employees makes it more necessary for companies to have experienced and competent senior management personnel to coordinate and manage human resources.

\section{Dilemma of Funding Supply}

Real estate development has a variety of different project financing models. One is that real estate developers rely on existing companies to carry out financing activities after identifying new real estate investment projects, and the other refers to the newly formed real estate development company for the financing of real estate projects. No matter which kind of financing mode is used, developers need to have considerable financial strength, that is to say, enterprises need multiple financing channels or strong self-owned capital, and these are exactly what private real estate enterprises lack and need. According to the 'State Council General Office's opinion on perfecting the anti-money laundering, anti-terrorism financing, and anti-tax evasion supervision system mechanism, the State Administration of Industry Letter [2017] No. 84', article 18 refers to the strengthening of abnormal transaction monitoring as an entry point to comprehensively use foreign exchange transactions monitoring, cross-border renminbi transaction monitoring and anti-money laundering funds transaction monitoring and other information, timely detection of cross-border money laundering and terrorist financing risks. Nowadays, Chinese supervision over funds has been intensified. At the same time, the lack of budget for some projects in the early stage of construction, so, the capital investment of companies has been greatly affected.

\section{Difficulties of Material Supply}

Laos has a poor industrial base. When private real estate enterprises invest in projects in Laos, they often need to start with infrastructure investment, which increases the burden and costs of the enterprises [12]. Moreover, the terrain in Laos is mainly mountainous, which brings great inconvenience to the construction of transportation facilities and communication facilities, and also brings higher risks for Chinese enterprises in mining and energy resources exploitation.

The supply capacity of raw materials in Laos is seriously insufficient, and enterprises can only seek supply from domestic sources. However, the long-term battle of many projects so that the further increase in transportation costs and the longer route. The high cost is a major burden for the enterprises. Each enterprise that invests in Laos can purchase together, and the cost of sourcing the same raw materials to the country is far lower than the separate purchase cost of the two.
However, each enterprise often considers others as potential competitors and purchases from suppliers respectively, which indirectly increases transportation costs and makes material supply more difficult.

\section{E. Lag of Progress}

Nowadays, the progress of some projects run by private real estate enterprises in Laotian lags behind, and the main reasons are the changes in policies and the poor cooperation of construction enterprises.

Although the Chinese government has vigorously promoted the development of related industries and curtailed restrictions on foreign investment. The construction enterprises must increase their research on international standards and actively adapt to international standards. The government encourages large enterprises to promote the cooperation of small and medium-sized enterprises and coastal enterprises along the coast. Actively and orderly develop the international market and avoid vicious competition. But, in 2018, the National Development and Reform Commission once again updated the "List of Foreign Investment-Sensitive Industries (2018 Edition)", which explicitly restricted real estate and other industries that are subject to irrational investment from investing overseas. For the real estate industry, the policy is still conservative.

The professional construction of real estate projects is carried out by different construction units. However, the process of projects is seriously hampered because of the poor familiarity and lack of communication between enterprises. Businesses investing in commercial real estate in Laos require a lot of information flow. Laos does not currently have the advantages of network media and the lack of efficient information transfer. As a result, enterprises cannot effectively regulate and control various resources of the project, take timely measures to cope with policy adjustments and delay in the supply of raw materials, etc. It delays the time of the construction and even leads to the stagnation of the project or generates so many of unfinished buildings.

\section{COUnTERMEASURES AND SUGGESTIONS}

\section{A. National Policy}

1) Creating a good international political environment

China should abide by its foreign policy objectives of safeguarding world peace and promoting common development It should unswervingly cooperate with all countries and actively participate in the settlement of environmental issues, refugee issues, and terrorism. China should give full play to advantages in the international market for Chinese enterprises to gain market share in transnational operations, and to seize opportunities in foreign investment [17].China must adhere to equal national interests and the interests of other countries and play an important role in international investment in handling state-to-state relations. It also should actively respond to the current trade protectionism imposed by the United States and other countries and properly resolve the contradictions that enterprises have in foreign investment. 


\section{2) Establishing a sound international policy coordination} system

Due to various reasons, Chinese private real estate enterprises often encounter various setbacks in the process of investing in Laos. The Chinese government can fully organize cooperation between countries and resolve disputes through international coordination [16]. China has gradually established a good bilateral and multilateral regional cooperation mechanism. Based on the existing variety of cooperation, it will promote the development of investment cooperation and exchange within the region. By signing a bilateral protection agreement to expand the scope of protection for enterprises abroad, the state should give full play to the political and diplomatic forces that cannot be replaced by enterprises. It should avoid as much as possible foreign companies from friction disputes, and provide a good environment for the internationalization of enterprises and foreign investment.

\section{3) Establishing a perfect overseas investment support} policy

The government must establish supportive measures for overseas investment by enterprises and try to minimize the impact of changes in domestic macro-control policies on private real estate enterprises. At present, most of the funds needed by private real estate enterprises to invest overseas are mainly from the loans of domestic banks. The success of corporate investment directly affects the ability of domestic banks to recover loans, as well as the domestic economy in China. Therefore, the Chinese government should pay more attention to the overseas investment of real estate companies and establish an overseas investment protection system for real estate enterprises. It provides insurance services for private real estate companies. The types of insurance include requisition insurance, foreign exchange insurance and war insurance, etc. After the fee, it has reduced the worries of enterprises investing overseas.

In addition, the government should provide support for private real estate companies with diversified financial policies, create policy conditions for the smooth financing of enterprises, simplify procedures and provide facilities in the financing process. When the investment income of a real estate company flows back to China, the enterprise is given a certain amount of tax incentives to allow the company to transfer the overseas investment income back to China and form a virtuous circle of funds [9].

\section{B. Enterprises}

\section{1) Implementing cross-cultural management}

Due to improper management of cultural conflicts, private real estate enterprises will have a great impact on the implementation of the project in the process of contracting Laos real estate projects. So, implementing cross-cultural management is indispensable. Cross-cultural management means that the enterprise adopt a series of measures to mediate and have achieved the business purpose of the enterprise when the home country and the host country have frictions due to cultural differences. China and Laos have certain synergies in terms of climate, clothing, and habits, and have a strong degree of cultural acceptance. Therefore, enterprises can adopt symbiotic or local management strategies in cross-cultural management. The symbiotic strategy means that when employees of different cultural backgrounds are in the same organization, the enterprise should hide and blur the friction between the two parties to make the differences between the two parties easily resolved. Localization strategy means that home-country enterprises should accept the host country culture as much as possible and have a global outlook on thinking. Localization is the guide in the actual implementation of the project. Therefore, private real estate enterprises should hire more local employees when investing in overseas projects, which is conducive to the development of projects in the host country.

\section{2) Training high-level international talents}

When private real estate enterprises invest in Laotian projects, senior management talents are seriously deficient. Talents with international operating experience are also lacking. The enterprises should actively develop international talents and play an important role in improving the success of the projects. Enterprises should scientifically formulate plans for international talent training according to their own development needs, so that talents have innovative and powerful cross-cultural management capability [3]. According to the target requirements, the enterprises internal personnel will be assigned to foreign companies to study, international talents will be inspected and a seminar for international personnel training will be organized regularly. Enterprises should improve the incentive mechanism for international talent cultivation, including salary incentives, business incentives, and cultural incentives, etc.

\section{3) Establishing diversified financing channels}

Real estate projects have the characteristics of large investment, large-scale development, long implementation period, etc. For financing, enterprises usually sign certain strategic cooperation agreements with banks in China or Laos. Due to the abnormal outflow of cross-border funds in China, the government has restricted the outflow of domestic funds. It caused some of the foreign exchange procedures previously handled by some of the Laos investment projects to be abolished and the capital chain has been broken. In the end, the project is to be stagnated.

Simplified financing channels enable companies to face a high degree of financial risks. Enterprises should be transformed from simplified to diversified financing channels through commercial banks and securities markets of the home country; capital markets of the host country, government assistance and other sources of funds to ensure the smooth implementation of the project. The enterprises should also establish an effective financial risk prevention mechanism to prevent related risks.

\section{4) Establishing a strategic alliance}

Each private real estate enterprise cannot manage its own affairs overseas, and it is necessary to form a joint force. if necessary, Sometimes, it is necessary to share resources. It will help enterprises jointly resist risks and form a strong strategic alliance. These mutual assistance and cooperation require a coordinating body, such as the local Chinese Chamber of Commerce in the host country, the Ministry of Commerce, and the Ministry of Foreign Affairs, etc. These organizations should 
often organize friendly exchanges between Chinese enterprises in the host country. Chinese enterprises cannot regard others as competitors, and they must establish the concept of "one plus one is greater than two" to create a good situation where all parties win together.

\section{5) Establish an effective cost control mechanism}

As a private enterprise implementing real estate projects overseas, effective cost control mechanisms should be established from the following aspects [10]: (1) Project land acquisition budget. Based on the relevant environment and background, a preliminary calculation of the cost of land acquisition will be carried out, and then an investment feasibility analysis will be carried out on the project to make a preliminary estimate of the maximum profit obtained. (2) According to the actual situation of the host country, carry out on-the-spot investigation, according to the type and positioning of the product, organize the accounting department to estimate the cost of the entire construction process. Making an estimate review of the entire project and finding out the situation of its own benefits. (3) Establishing the first draft of cost planning instructions. The basis of the cost budget is sorted out and the cost indicative document is produced. On the one hand, analyzing project feasibility, on the other hand, ensuring the smooth implementation of the project. (4) Dynamic monitoring of costs. The indicators are implemented in various departments of the enterprises, and then the department implements the specific responsible personnel. It must implement according to the estimated cost index when departments work. All materials required for the project, staff salaries and other expenses must be included in the cost index. During the period, may be changes and conclusions of the contract will be generated. It is necessary to monitor the cost dynamically and formulate the elimination measures for the difference so that the enterprise can achieve the preset business objectives.

\section{CONCLUSION}

From the perspective of private real estate enterprises, the paper has analyzed the difficulties and causes of the project investment in Laos, and given corresponding countermeasures and suggestions.

The conclusions are as follows: Firstly, this paper analyzes the macro and micro environment of the international development of Chinese private real estate companies, and concludes that it is necessary and feasible for Chinese private real estate companies to invest in Laos.

Secondly, private real estate enterprises are in trouble during the process of project investment, and the reasons are as follows: (1) Cross-cultural communication difficulties, resulting in cultural conflicts, etc. (2) Lack of high-level management talents. (3) Difficulties in material supply (4) Difficulties in funding and poor financing (5) Progress is lagging behind, and national policies restrict the flow of capital and weaken the ability to collaborate between construction departments.

Thirdly, from the perspective of countries and enterprises, put forward countermeasures and suggestions. On the one hand,
China must strengthen the international cooperation of other countries, establish a sound overseas investment support policy and provide a good international and domestic environment for the internationalization of enterprises. On the other hand, enterprises should strengthen cross-cultural management, foster high-level international talents, establish multiple financing channels, establish strategic alliances with host governments and enterprises, and make assessments in advance, etc.

To sum up, Chinese private real estate enterprises investment in South Asia and Southeast Asian countries is the future trend. The demand for development at the current stage in a country similar to Laos is highly consistent with the capacity supply proposed by the "Belt and Road'. This study has a clear investment-oriented meaning.

\section{ACKNOWLEDGMENT}

We would like to express our sincere gratitude to International Business School of Yunnan University of Finance and Economics for providing us with an opportunity for publication. We also want to thank Dr.Yin Hao for his support and guidance.

\section{REFERENCES}

[1] An Jiali. The Impact of Laos Investment Environment on Investment Willingness of Chinese Enterprises[D]. Inner Mongolia University, 2017:15-23.

[2] Deng Wu. Research on Human Resource Management Model of Multinational Corporation[J].Human Resources.2013,6.

[3] Fu Shaoli. Research on cross-cultural human resources management of multinational corporations in China[D]. Chongqing Technology and Business University, 2012

[4] Fu Yongqing. Analysis of the Investment Risks of Chinese Enterprises to Laos[J]. China International Finance (in Chinese, English), 2017(17):231-232

[5] Huang Qing. Cultural Conflict and Integration of Transnational Corporations and Cross-cultural Management Strategies [J]. Contemporary Economy. 2011, 5:46-47.

[6] Huang Renjie. Development Trend of International Investment Policy [J]. Investment and Cooperation. 2015, 1:51-54.

[7] Lei Xiaomiao. Face up to cultural differences and develop cultural identity - cross-cultural management in transnational corporations [J]. Business Studies. 2017, 1: 13-18.

[8] Li Ping. Points of Law, Regulations and Policy for Laos Trade and Investment [N]. China Industry News, 2018-03-22(008).

[9] Li Shucheng. Research on China's Foreign Direct Investment Promotion Mechanism from the Perspective of Institution[D]. Capital University of Economics and Business, 2013.

[10] Peng Xue. Research on the collaborative management of financial management and cost control in real estate enterprises [D]. Jilin Architectural University, 2013.

[11] Sang Baichuan, Li Yumei. Comparison of International Investment Rules, Trends and China's Countermeasures [J]. Comparative Economic and Social Systems. 2014, 1: 176-188.

[12] Shi Zhiyong. Analysis of State-owned Enterprises Risk Control of Overseas Contract Projects [J]. China Chief Accountant, 2012,(8): 106-107.

[13] Shu Min, Li Jun. The Importance of Plan Management in Project Management [J]. Management Review, 2012, (2): 27-28.

[14] Wan Sai, Hou Fengyun. Research on the Development of Economic and Trade Relations between Laos and China under the "Belt and Road" Strategy [J]. Contemporary Economy, 2017(20):4-5. 
[15] Zhan Xiaoning. A New Path to Global Investment Governance "Understanding the Guiding Principles of G20 Global Investment Policy" [J]. World Economy and Politics. 2016, 10: 4-18+155.

[16] Zeng Huaqun. The current trend of international investment policy and Chinese due [D]. Guangming Daily. 2013.8
[17] Zhu Caihua, Li Nuo. Development Trend of Global Investment Policy and Construction of Belt and Road Investment Cooperation Treaty Network [J]. International Trade. 2016.9:58-65. 